\title{
教育講演 一抄録一
}

\section{第2日・9月10日 (火) 8：00 9：00 B 会場 How to Session (Video)}

\author{
座長：井上 博 (富山医科薬科大学第二内科) \\ 心房細動のカテーテルアブレーション
}

熊谷浩一郎 (福岡大学医学部循環器科)

\section{I ．はじめに}

Haïssaguerre らは心房細動 $(\mathrm{AF})$ の開始機序を検討し たところ，トリガーとなる心房性期外収縮 (APB)の $90 \%$ 以上が肺静脈 (PV) 内の心筋から発生することを発 見し，これらの起源に対するアブレーションにより $\mathrm{AF}$ を根治しうることを報告した。報告当初は比較的若年者 で基礎心疾患がなく, 毎日反復して生じる非持続性 $\mathrm{AF}$ を focal AF と定義し, 局所アブレーションの適応と考え られた。その後，持続性及び慢性 $\mathrm{AF} に$ にいても， $\mathrm{AF}$ 開始のトリガーとなる APBの $90 \%$ 以上がPV内から発生 することが明らかとなり, 適応はさらに拡大されてきた。

\section{II.PVアブレーションの実際}

1) 適応

発作時の症状が強く, 薬剂抵抗性の AFがアブレー ションの適応となる。発作頻度が高く, ホルターでも $\mathrm{APB} ， \mathrm{AF}$ を頻回に認める例が良い適応といえる．また， レートコントロールが困難な例や, 心不全のためI群抗 不整脈薬が使用できない例も適応となる，筆者らの検討 では成功の規定因子として年齢， $\mathrm{AF}$ 歴，左房径，起源

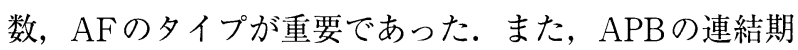
が短いこと (P-on-T pattern)がPV起源の特徵といわれ ている.

2) 最早期興奮部位に対する局所アブレーション法

Haïssaguerreらは発作のトリガーとなるAPB起源部 位を標的としたアブレーションによって AFが根治可能 であることを報告した。しかし, 複数の起源全てが一回 の検查中に出現するとは限らず，また再現性をもって 382
PVからの発火を誘発する方法がないためアブレーショ ンの効果を判定するエンドポイントが不明暸であること から，最近では局所アブレーション法に代わって次に述 べるPVを電気的に隔離する方法が普及している.

3) $\mathrm{PV}$ isolation

HaïssaguerreらはPV 電位の消失または左房電位との 解離がアブレーションの成功規定因子として重要である と述べた。しかし PV 入口部全周を線状焼灼することは 困難である。そこで，彼らはリング状カテーテルを開発 し，PV入口部を全周にわたってマッピングしたところ， 左房から PVへの興奮伝搬は全周にわたって同時ではな く，一部に早期性を示す部位があることを報告した．興 奮の早期性を示す部位は左房-PV 間電気的侵入部位 (electrical breakthrough)と考えられ，その部位のみの 焼灼により，左房-PV 間の伝導ブロックが作成される. 心房中隔穿刺後，左房内にロングシースを挿入し，これ を介してPV入口部にリング状カテーテルを留置し，PV 入口部全周のPV 電位を同時記録する(図 1 ). 右上PVで は洞調律時に，左上PVでは冠状静脈洞遠位部からの ペーシングにより PV 電位を顕性化し, electrical breakthroughを同定する.アブレーションは50度の温 度設定かつ $30 \mathrm{~W}$ 以下で 30-60秒間通電する。最早期 PV 電位部位における通電後, その部位の伝導が遅延し, 最 早期部位が他の部位に移動する場合は，左房-PV 間には 複数の進入部位が存在すると考えられる. 最早期 PV 電 位部位に相応する PV 入口部局所の焼灼で全周のPV 電 位が突然消失し，電気的 PV 隔離が作成される(図2).

第19回日本心電学会学術集会プログラム抄録集 : 名古屋, 2002 


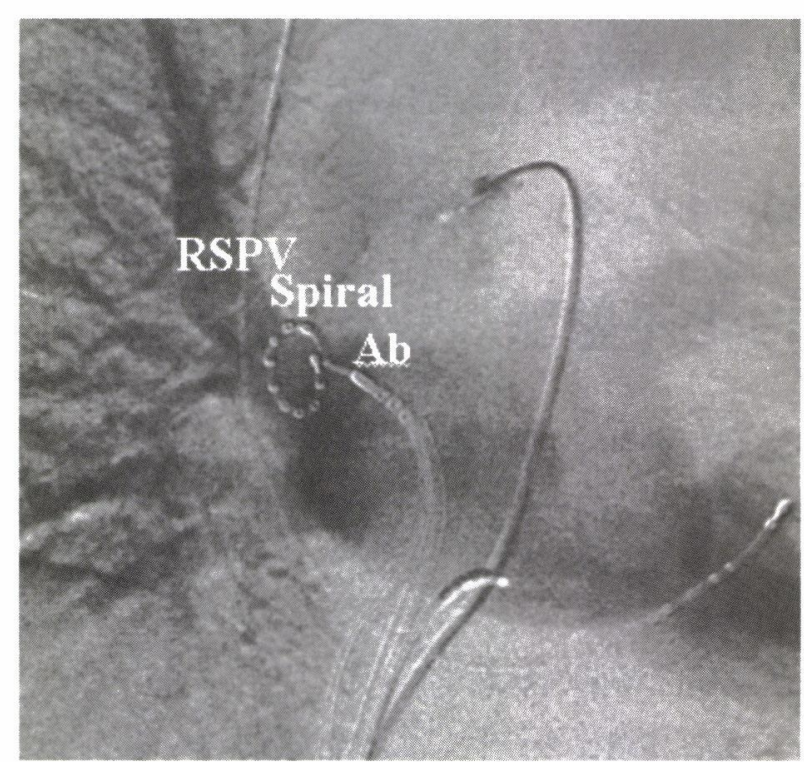

RSPV

図 1 PV isolation

肺静脈入口部に 10 極リング状カテーテルを留置し, 最早期 肺静脈電位部位を焼灼する. RSPV = right superior pulmonary vein, LSPV = left superior pulmonary vein, $\mathrm{Ab}=$ ablation catheter.

筆者らは発作性 AF47例で, 明らかに心房波から分離し たPV電位を有した108PVに対しPV isolationを行った (1PV : 11 人, $2 \mathrm{PV}: 12$ 人, $3 \mathrm{PV}: 23$ 人, $4 \mathrm{PV}: 1$ 人). 1 回目のセッション後 47 例中 22 例で AF が再発したが, そのうち 15 例で 2 回目のセッションを施行した。平均 8 ケ 月の経過観察期間の成功率は $68 \%$ あったた. 再発の原 因は主に左房-PV 間伝導の回復によるが, PV 以外の心 房自由壁からの起源によることもあった。術後, 心囊液 貯留を 1 例， $1 \% 4$ 半盲を 1 例に認めたが，PV狭窄は認め なかったＰV狭窄の頻度は少ないといわれているが， 起こりうる合併症である. 入口部のみで, しかも低出力で 焼灼すれば多くの場合, 危険は回避できると考えられる。

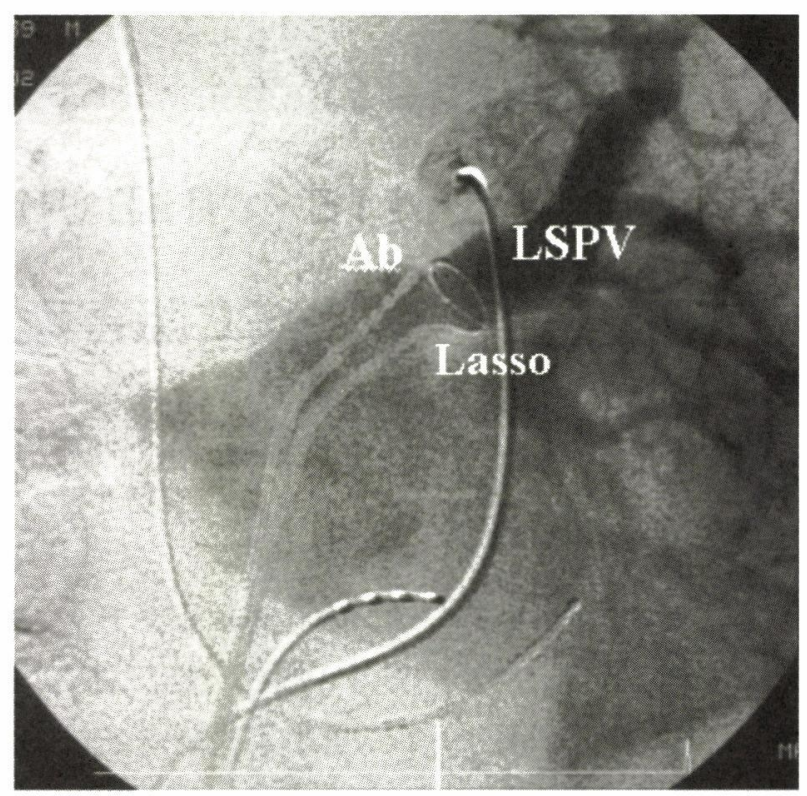

\section{LSPV}

図2 PV isolationにおける左房-肺静脈間電気的侵入部 位の同定

右上肺静脈入口部にリング状カテーテルを留置し, 洞調律中 に肺静脈入口部全周の肺静脈電位を同時記録した. 最早期肺 静脈電位を認めた部位 (電極3-4) での焼灼後, 局所の伝導が 遅延し, 次の最早期興奮部位 (電極 6-7, 7-8) を燒灼すること ですべての肺静脈電位の消失に至った (breakthrough 部位は 2 ヶ所).

$\mathrm{A}=$ atrium, $\mathrm{PVP}=$ pulmonary vein potential, $\mathrm{HRA}=$ high right atrium, $\mathrm{CS}=$ coronary sinus, $\mathrm{SP}=$ spiral catheter, $\mathrm{ABL}=$ ablation catheter, $\mathrm{d}=$ distal, $\mathrm{p}=$ proximal.

\section{III. おわりに}

現時点ではすべての AFが適応とはならないが，比較 的若年者で器質的心疾患の軽度な発作性 AF 例などは有 効率が高いと考えられる. 今後, テクノロジーの進歩に より，容易にしかも確実に焼灼できるようになれば，成 功率が上昇し, 適応が拡大されることが期待される。 